\title{
Pork, Peace and
}

Principles: the Relations between the EU and the Eurasian Economic Union

\section{Professor Rilka Dragneva-Lewers (University of Birmingham)}

(C) The Author(s)

Institute of European Law Birmingham Law School University of Birmingham Edgbaston

Birmingham

B15 2TT

United Kingdom

For more information on the IEL, see:

birmingham.ac.uk/IEL

For more information on this Working Paper Series, please contact:

IEL Administrator: iel@contacts.bham.ac.uk

\section{Institute of}

European Law

Working Papers

\section{Paper:}

$02 / 2019$ 


\title{
Pork, Peace and Principles: the Relations between the EU and the Eurasian Economic Union ${ }^{1}$
}

\author{
Rilka Dragneva-Lewers \\ Professor of International Legal Studies \\ University of Birmingham \\ Birmingham Law School
}

\begin{abstract}
Over the last decade the EU faced numerous calls to engage with the Customs Union between Russia, Belarus and Kazakhstan set up in 2010 and its successor, the Eurasian Economic Union (EAEU), found in 2015. While proponents differ in terms of their justification and desired scope of cooperation, they share the view that it should take place on a region-to-region basis, thus representing an important departure from the EU's approach to the post-Soviet countries. The EU's reluctance to embark on such a course so far has been attributed to the political crisis of EU-Russia relations, especially in the aftermath of the annexation of Crimea and the war in Eastern Ukraine. In this context, for some, a mega-deal contains not just the promise of economic cooperation and connectivity, but also represents the means to improve relations with Russia and restore peace and stability in Europe.

This paper argues that while these are worthy objectives, the utility of a region-to-region engagement with the EAEU should be premised on a realistic assessment of the nature of Eurasian integration as well as informed by the priorities in EU's external economic relations following its 2006 Global Europe strategy, more generally. To this end, the paper examines the EAEU against three particular dimensions: the extent to which it represents a unified regional actor, its trade liberalisation credentials and its ability to meet the EU's values conditionality. It concludes that the EAEU's institutional set up and practice exhibits fundamental problems in all of them. This means that the expected benefits of a regional mega-deal with the EAEU are highly uncertain, but also that moving away from a bilateral mode of engagement will entail significant departures from EU's principles and approach to external relations more generally.
\end{abstract}

\footnotetext{
${ }^{1}$ A revised version of this paper will be published in R. Petrov and S. Lorenzmeier, 'Contemporary Issues of EU External Relations: From Shared Competences to Shared Values' (Springer, 2019).
} 


\title{
Pork, Peace and Principles: the Relations between the EU and the Eurasian Economic Union ${ }^{2}$
}

\author{
Rilka Dragneva-Lewers
}

Over the last decade the European Union (EU) faced numerous demands to engage with the Customs Union (CU) between Russia, Belarus and Kazakhstan set up in 2010 and its successor, the Eurasian Economic Union (EAEU), found in 2015. The pursuit of EAEU's recognition as an equal partner of the EU has been a priority of Russia's foreign policy since the launch of Vladimir Putin's third presidency in late 2011. In particular, Moscow called for establishing a common economic space from the Atlantic to the Pacific by developing relations between the two blocs. ${ }^{3}$ Nonetheless, despite some discussion on a policy shift, the EU has maintained only low-level, selective technical contacts with the EAEU.

For Moscow, EU's stance amounts to ignoring the EAEU in denial of Russia's right to integration (Bordachev 2015, Chizhov 2017). Russia has objected to the EU's imposition of any 'political conditionality', such as the implementation of the Minsk peace agreements, for starting a dialogue: in the words of Dmitrii Peskov, President Putin's speaker, this was 'hardly relevant or possible'. ${ }^{4}$ Such statements claim that the EAEU is not Russia's political tool but an independent international organisation pursuing purely economic objectives in line with modern tendencies of regionalism. Accordingly, it has been argued that ' $T$ T] he dialogue between the EAEU and the EU needs to start without any preliminary conditions or political context considerations'. ${ }^{5}$

In the EU, the idea for engagement has also enjoyed the support of some academics, policy experts, business lobbies and politicians, albeit with pronounced differences in justification and vision as to its ambition and parameters (Krastev, Leonard 2014, Meister 2015, Bertelsmann Stiftung 2016, IIASA 2016, 2017, Felbermayr, Gröschl 2017, Ademmer, Lissovolik 2018). What many of them share is the view that the current state of affairs is rooted in the political crisis in EU-Russia relations. The assumption is that, should the political clouds clear, EU-EAEU cooperation is 'a matter of when not if' (Dreyer 2016). Others promote EU-EAEU

\footnotetext{
${ }^{2}$ A revised version of this paper will be published in R. Petrov and S. Lorenzmeier, 'Contemporary Issues of EU External Relations: From Shared Competences to Shared Values' (Springer, 2019).

${ }^{3}$ E.g. see Foreign Policy Concept of the Russian Federation, 30 November 2016. http://www.mid.ru/en/foreign_policy/official_documents/-

/asset_publisher/CptICkB6BZ29/content/id/2542248 (accessed 25 October 2018).

${ }^{4}$ Reported in Gotev (2015).

5 Statement of the Minister of the Eurasian Economic Commission, Tatyana Valovaya, Eurasian Economic Commission News Update. Ministr EEK Tat'yana Valovaya: Dialog mezhdu EAES I ES cleduet nachat' bez predvaritel'nykh uslovii I oglyadki na politicheskii kontekst. 11 October 2018. http://www.eurasiancommission.org/ru/nae/news/Pages/11-10-2018-1.aspx (accessed 26 November 2018).
} 
dialogue as the particular means to clear those clouds by shifting the competition between Russia and the West back onto an economic field rather than a military one' (Krastev, Leonard 2014). Thus, engagement with the EAEU is seen as an economic confidence-building measure with economic connectivity offering the answer to European security (International Peace Institute 2016). Notably, while there is little consensus as to the substantive scope of such engagement - upgraded dialogue, sectoral and regulatory cooperation, or a deep and comprehensive deal with or without free trade - the view is that it should take place on a region-to-region basis through the representative institutions of the two blocs, namely the European Commission and the Eurasian Economic Commission (EEC).

Importantly, such assertions tend to assume a functional equivalence between the EU and the EAEU in terms of integration frameworks, or recognise certain differences between them but downplay their significance in favour of the wider benefits of procuring good relations with Russia. This, however, represents a pivotal flaw in the engagement argument. Ignoring or underestimating the specificity of Eurasian integration to secure an instrumental engagement with the EAEU will not only fail to deliver the expected solution, but risks undermining EU's interests and standing. This is not to say that developing relations with the region is not in the interest of the EU. Economically, for example, the 2006 Global Europe strategy already identified Russia as a desired partner with which to conclude a free trade agreement. ${ }^{6}$ More recent estimates echo this, noting that European exports can increase by as much as $60 \%$ compared to the 2011 status if such an agreement were to be concluded (Felbermayr, Gröschl 2017: 57). The question is about the extent to which Eurasian integration in its current state is conducive to a region-to-region approach as opposed to developing bilateral relations or formats of engagement short of 'pure transregionalism' (Aggarwal, Fogarty 2004).

In determining the prospects for a region-to-region deal, it is especially important to scrutinize the nature of the EAEU in relation to some of the key characteristics of EU's external economic policy in general. Three dimensions are of particular relevance here. Firstly, in principle, the EU's trade strategy has entailed a normative preference for negotiating with regions rather than with individual countries. Yet, while many negotiations have started as region-to-region, very few have completed. The extent to which the EU has engaged with a 'region' as a negotiating partner has depended on a number of factors, including the ability of EU's partners to progress towards regional integration and the diversity of preferences and economic development levels within a region (Aggarwal, Fogarty 2004, Woolcock 2014).

Secondly, EU's approach to concluding trade agreements with third parties is rooted in its overarching support for multilateral trade liberalisation in the framework of the WTO. In embarking on its Global Europe strategy, the EU lifted its stay on preferential trade

\footnotetext{
${ }^{6}$ European Commission. Communication from the Commission to the Council, the European Parliament, the European Economic and Social Committee and the Committee of the Regions of 4 October 2006. Global Europe: Competing in the world. https://eur-lex.europa.eu/legal-content/EN/TXT/?uri=LEGISSUM\%3Ar11022 (accessed 26 November 2018).
} 
agreements in favour of combining regionalism with multilateralism. However, EU's decision to enter into such agreements remains premised on the adherence to WTO rules and principles, including the promotion of a WTO-plus agenda (Woolcock 2012).

Finally, while commercial considerations have increasingly determined its choice of negotiating partners (Woolcock 2014), EU's external relations are embedded in a set of fundamental values. This is particularly so following the 2009 adoption of the Lisbon Treaty which defines the goals of the EU's Common Commercial Policy not just in terms of promoting liberalisation (Article 206 TFEU), but also makes them subject to the general principles of EU's external action (Article 207:1 TFEU). These principles include support of democracy, the rule of law, human rights, peace and the principles of international law (Article 21:2 TEU). In practice, the EU's approach has not necessarily been consistent in terms of the scope and enforceability of the human rights and other 'essential element' clauses used in its external agreements (Bartels 2005). Nonetheless, the value-dimension of the EU's external dealings has grown in prominence, strengthened further by the greater role granted to the European Parliament in external affairs (Gstöhl, Hanf 2014).

This chapter assesses Eurasian integration against these dimensions of EU's external policy. The analysis starts with a discussion of the status quo of EU's relations with the Eurasian region and the tensions already observed before exploring the institutional nature and practice of the EAEU. On balance, it arrives at a sceptical conclusion about the prospects for a change in EU's current approach beyond the likelihood of ceasefire in Ukraine.

\section{The Background of EU's policy towards Eurasian integration}

Following the break-up of the USSR, EU's relations with its former members developed on a bilateral basis. To a large extent this was in response to the disintegration processes taking place within the post-Soviet region itself. Initially, Russia under Eltzin was keen to define itself in opposition of the Soviet Union and forge ahead with reform and improve relations with the West, ridding itself from the burden of its former brothers. The other republics were also keen to establish their own sovereignty, engaging in an intensive process of independent statebuilding. While efforts to re-unite the region followed soon, resulting in the formation of the Commonwealth of Independent States (CIS) in December 1991, the initial impulse behind it was one of a managed divorce. Unsurprisingly, the CIS was set up as a loose cooperation framework with weak common institutions (Dragneva 2004). While gradually moving to strengthen the $\mathrm{CIS}$ and promote economic integration within it, Moscow remained unwilling to bear the associated costs, preferring to pursue trade relations within the bloc on a bilateral basis (Cooper 2009, Dragneva, de Kort 2007).

Against this background, the EU committed to the conclusion of Partnership and Cooperation Agreements (PCAs) with individual post-Soviet countries with the aim to establish a 
comprehensive economic and political partnership framework. ${ }^{7}$ A negotiating mandate was obtained by the Council in 1992 with the first negotiations, with Russia and Ukraine, starting in early 1993. It may be argued that, to start with, the EU conceived of the newly independent states (excluding the Baltic States) as a distinct and homogeneous region. It developed the PCA as a tailor-made agreement in distinction from its agreements with the countries of Central and Eastern Europe (Hillion 1998). Politically, the EU was also keen to foster regional cohesion: the PCA Preambles, for example, noted the desire to encourage the process of regional cooperation ... between the countries of the former USSR in order to promote the prosperity and stability in the region' ${ }^{8}$

Nonetheless, the PCAs introduced a clear differentiation with regard to individual countries. ${ }^{9}$ Notably, the agreements with Russia and the Eastern CIS contained an 'evolutionary clause' allowing for the progression towards a free-trade area. This differentiation deepened in the context of the EU's Eastern enlargement. In 2003, the EU launched its Eastern Neighbourhood Policy (ENP), but taking into account Russia's objections to being defined as one of the Union's many 'neighbours', it elevated it to the role of 'strategic partner' (Haukkala 2008). At the same time, the PCA with Belarus was not ratified and it was excluded from the ENP in response to the political conditions in the country (Bosse, Korosteleva 2009). ${ }^{10}$ Thus, building on the legal basis of the PCAs, a diversified policy approach to the post-Soviet region was established. With Russia, the EU embarked on a 'partnership' agenda aimed at the creation of Common Spaces. ${ }^{11}$ In 2005, this led to the adoption of four 'road maps', among them a road map on the common economic space, which reaffirmed the goal of creating a free-trade area. With the Eastern CIS and the Caucuses, the EU developed various Action Plans under the ENP. Relations evolved within the 2009 Eastern Partnership framework entailing the conclusion of

\footnotetext{
7 The EU had signed a Trade and Economic Cooperation Agreement with the USSR in December 1989. Following the break-up of the USSR, this agreement was transformed into a set of bilateral agreements, which were in place until the PCAs.

${ }^{8}$ Similarly, the EU's technical assistance programme for the CIS, TACIS, had an important regional component. ${ }^{9}$ PCA between the EC and their Member States, of the one part, and the Russian Federation, of the other part (OJ 1997 L327/1), PCA between the EC and their Member States, of the one part, and Ukraine, of the other part (OJ 1998 L49/1), PCA between the EC and their Member States, of the one part, and Moldova, of the other part (OJ 1998 L181/1), PCA between the EC and their Member States, of the one part, and Armenia, of the other part (OJ 1999 L239/1), PCA between the EC and their Member States, of the one part, and Azerbaijan, of the other part (OJ 1999 L246/1), PCA between the EC and their Member States, of the one part, and Georgia, of the other part (OJ 1999 L205/1), PCA between the EC and their Member States, of the one part, and the Republic of Kazakhstan, of the other part (OJ 1999 L196/1), PCA between the EC and their Member States, of the one part, and the Kyrgyz Republic, of the other part (OJ 1999 L196/46), PCA between the EC and their Member States, of the one part, and Uzbekistan, of the other part (OJ 1999 L229), Proposal for a PCA between the EC and their Member States, of the one part, and Belarus, of the other hand (Com(95)44), Proposal for PCA between the EC and their Member States, of the one part, and Turkmenistan, on the other hand (COM(1997)693).

10 In 1997 the EU suspended the process of ratification of the PCA with Belarus, continuing to deal with it on the basis of the 1989 Trade and Cooperation Agreement.

${ }^{11}$ EU-Russia Summit, Joint Statement, St Petersburg, 31 May 2003.

https://www.consilium.europa.eu/uedocs/cms_data/docs/pressdata/en/er/75969.pdf (accessed 28 August 2018).
} 
Association Agreements (AAs) with the EU. ${ }^{12}$ Relations with the Central Asian countries were least ambitious, developing within the broad cooperation framework of the EU's Central Asia Strategies. ${ }^{13}$

These policies were not related to Russia's string of integration initiatives in the 1990s and the early 2000s. This was hardly surprising given their primarily rhetorical nature and weak institutional set-up. The Eurasian Economic Community (EAEC) between Russia, Belarus, Kazakhstan, Kyrgyzstan and Tajikistan established in October 2000 was the first post-Soviet integration organisation with its own international personality and well-defined bodies. Yet, like its predecessors, it failed to lead to any meaningful implementation, feeding the cycle of fatigue with 'the virtual reality of integration' (Shishkov 2001: 7). At the same time, despite Russia's efforts to secure more equal relations with Brussels in response to its growing concern about the EU's asymmetric normative expansion (Haukkala 2010), Moscow did not invoke its own integration efforts.

The context began to change in 2007, when restarting their integration efforts, Russia, Belarus and Kazakhstan committed to setting up a Customs Union (Dragneva, Wolczuk 2012, Cooper 2013). The project did not entail the birth of a new regional organisation: it represented an international treaty regime tagged awkwardly onto the EAEC (Dragneva 2013). Nonetheless, it gradually accumulated its own legal basis, progressing to the launch of a common external tariff (CET) in January 2010 and a common customs territory based on a Union Customs Code in July 2010. In light of the previous failed efforts to reintegrate the region and the incremental gestation of the Customs Union, EU's initial reaction to these developments was one of caution. Its subsequent response was shaped by three main sets of considerations.

\section{The CU and Russia's WTO accession}

The EU's initial concern in relation to the launch CU was about its effect on Russia's WTO accession. Russia had applied for WTO membership in June 1993, but the negotiations proved to be difficult and protracted. The EU completed its bilateral market access negotiations with Moscow in May 2004 and was anticipating Russia's accession to the WTO to bring significant benefits. In particular, Brussels was hoping for an impetus to develop its increasingly stagnating bilateral relations and a relief to the build-up of costly trade disputes with Russia (Van Elsuwege 2012, Van der Loo 2013). However, in May 2009, the then Prime Minister Putin announced a plan for Russia to enter the WTO not individually, but alongside Kazakhstan and Belarus as part of a single customs union bloc. Apart from opening a legal quagmire as to the possibility for such a step, this led to even more uncertainty about the prospects for Russia's

\footnotetext{
${ }^{12}$ Council of the European Union, Joint Declaration of the Prague Eastern Partnership Summit, Brussels, 7 May 2009. https://www.consilium.europa.eu/media/31797/2009_eap_declaration.pdf (accessed 28 August 2018). ${ }^{13}$ Central Asia Strategy Paper 2002-2006 \& Indicative Programme 2002-2004. http://trade.ec.europa.eu/doclib/docs/2004/july/tradoc_118014.pdf; The EU and Central Asia: Strategy for a New Partnership, Brussels, 31 May 2007. https://eeas.europa.eu/sites/eeas/files/st_10113_2007_init_en.pdf (accessed 28 August 2018).
} 
accession to the WTO given that Belarus and Kazakhstan were a lot further behind in the accession process than Russia (Lynn 2009).

After much opposition from within the WTO, the plan was abandoned in October 2009 with Russia returning to the table on its own. However, a solution to the coexistence of the CU involving two non-members, Belarus and Kazakhstan, with the multilateral trading system was not found until October 2011, when the Treaty on the Functioning of the Customs Union in the Multilateral System was signed. The Treaty incorporated Russia's accession commitments within the CU framework, providing for the supremacy of the WTO regime (Connolly 2013). This step cleared the path to the WTO Working Party agreeing on Russia's accession in November 2011, which became effective in August the following year.

The problems for the EU, however, did not disappear. The CU's external tariff incorporated the tariff increases adopted by Russia as part of its extensive protection measures introduced in 2009. This also meant that more open countries, such as Kazakhstan, had to raise their tariffs to the level of the CU. In consequence, the overall costs for the EU as the region's main trading partner were high. ${ }^{14}$ These costs were aggravated by the fact that Russia did not formally notify the EU of the introduction of the CET nor did it agree to hold consultations with the EU under Article 16 of the PCA before increasing tariffs. ${ }^{15}$ In addition, the introduction of the CU was not well prepared in administrative terms, leading to disruption of trade through border delays and legal uncertainty. Finally, a number of Russian/CU sanitary and phyto-sanitary (SPS) measures, including an all-EU import ban on vegetables in November 2011 and on live animals in March 2012, were deemed to be disproportionate and discriminatory. As Russia's accession had not yet taken effect, the formal legality of these steps under the WTO was not necessarily at stake (Van der Loo 2013). Yet, against the background of Moscow's increasingly protectionist stand, they threw further doubt on Russia's commitment to play by the WTO rules. On balance, the impression was that the CU had de-liberalisation effects and was not WTO-consistent.

\section{The CU and the New Basic Agreement (NBA) with Russia}

The launch of the CU also impacted on the course of EU's bilateral relations with Russia. Entering into force in December 1997, the PCA laid the groundwork for developing political and economic cooperation between its parties. It was concluded for a period of 10 years subject to automatic annual renewal thereafter to ensure its continuation. Yet, there was a

\footnotetext{
14 By the end of 2009, for example, Russia was responsible for around $75 \%$ of all EU exports facing increased border protection worldwide. See European Commission, Report on the progress achieved on the Global Europe strategy, 2006-2010. Commission staff working document. 12 November 2010. http://trade.ec.europa.eu/doclib/docs/2010/november/tradoc_146941.pdf (accessed 26 November 2018); European Commission, Customs Union between Russia, Belarus and Kazakhstan: implementation - state of play. Communication to the INTA Committee and Member States. December 2010. http://trade.ec.europa.eu/doclib/docs/2010/december/tradoc_147124.pdf (accessed 26 November 2018).

${ }^{15}$ Article 16 provides that '[u]ntil Russia accedes to the GATT/WTO, the Parties shall hold consultations in the Cooperation Committee on their import tariff policies, including changes in tariff protection. In particular, such consultations shall be offered prior to the increase of tariff protection.'
} 
recognition that the PCA was increasingly outdated for the 'strategic partnership' with Russia (Van Elsuwege 2012). Thus, in 2005, as the package of Common Spaces road maps was adopted, a political agreement was reached to conclude a New Basic Agreement to replace the PCA. This agreement was meant to be comprehensive in scope, covering all aspects developed under the road maps, including trade, investment and energy, but also legally binding in nature. ${ }^{16}$

Yet negotiating the agreement proved to be slow and problematic. The start of the talks was delayed as a result of the blockage imposed by Poland in response to the Russian import ban on Polish meat (Roth 2009). ${ }^{17}$ Political relations were also strained following the 2008 RussiaGeorgia war. After temporary optimism fuelled by President Medvedev's modernisation programme and the adoption in the 2010 Partnership for Modernisation, negotiations ground to a halt. This was not only because of the uncertainties around Russia's WTO accession, discussed above, which for the EU was a precondition for progressing towards the free trade agreement envisaged under the PCA. Increasingly, deeper differences began to emerge related to trade and investment preferences, but also to the normative fundamentals of EURussia relations with Russia increasingly becoming an 'unwilling partner' of the EU (Casier 2018).

It should also be noted that within Russia itself the processes of setting up the Customs Union and negotiating the NBA with the EU were not coordinated. The formation of the Customs Union and its effects on bilateral relations with the EU was not raised as an issue at EU-Russia summits at the time. For example, the Joint Statement following the 1 June 2010 Rostov-onDon summit which took place as the Customs Union was being launched amidst much domestic publicity, makes no mention of it, continuing to reaffirm the course towards negotiating a NBA.

With the return of Vladimir Putin to the Russian Presidency in the spring of 2012, however, things began to change. For Putin, Eurasian integration had a pronounced strategic geopolitical significance (Dragneva, Wolczuk 2017). Proposing the formation of a Eurasian Union, he viewed it as 'one of the poles of the modern world' and an equal partner to the EU. ${ }^{18}$ In June 2012, at the first EU-Russia summit following the presidential elections, Putin made it clear that Russia will not progress with the NBA negotiations unless the EU formalises relations with the Eurasian bloc, including the establishment of direct dialogue between the European Commission and the Eurasian Economic Commission. As Putin argued, '[E]ven if we

\footnotetext{
${ }^{16}$ Joint Statement of the EU/Russia Summit on the Launch of Negotiations for a New EU/Russia Agreement, Khanty-Mansiysk, 27 June 2008. http://en.kremlin.ru/supplement/286 (accessed 28 November 2018).

${ }^{17}$ The European Commission had tabled a draft negotiating directive for a new Russia-EU agreement in July 2006.

18 'Novyi integratsionnyi proekt dlia Evrazii - budushchee, kotoroe rozhdaetsia segodnia. Izvestiya, 4 October 2011.
} 
wanted we cannot anymore discuss with the EU as part of the negotiation process issues which do not any more represent part of our national competences.' ${ }^{19}$

The EU at the time did not engage with this point, other than to state its own lack of mandate for such negotiations. Instead, speaking at the June 2012 summit, the President of the European Council, Herman Van Rompuy, noted that ' $[T]$ he idea of the Eurasian Economic Union if based on the WTO-rules could lead to positive contribution to trade, prosperity and cooperation. ${ }^{20}$ Yet, the EU's continued preference for a bilateral agreement was based on the view that this pre-condition was not in place. Moscow's assertion that even though Belarus and Kazakhstan were not current members of the WTO, they have undertaken to be bound by Russia's accession obligations and the WTO acquis, ${ }^{21}$ was not sufficient for the EU to commit to a region-to-region agreement. For example, a working party of the Council of the EU pointed out the problem that non-WTO members will not be bound by its dispute settlement rules (EPRS 2017: 11). Even more importantly, Russia and the CU were not seen as fully complying with WTO rules and commitments. While this view was frequently voiced by representatives of the Commission's DG Trade (Euractiv 2012), it also enjoyed the support of the European Parliament. ${ }^{22}$ In March 2013, the Commission President Barroso reiterated the position that cooperation depends on the EAEU operating on the basis of 'open regionalism instead of regional protectionism'. ${ }^{23}$ Yet, having joined the organisation, Russia seemed to be 'doing exactly the opposite of what they are supposed to do [...] by seeking to raise obstacles to trade' (Crouch 2013).

\section{The $\mathrm{CU}$ and the Eastern Partnership}

The launch of the CU also had a pronounced effect on EU's European Neighbourhood Policy (Delcour, Wolczuk 2013). This was because one of the defining features of the Eurasian project was the pursuit of its expansion to the common neighbourhood with the EU. This is consistent with Russia's geopolitical motivation behind regional integration, but also its particular sensitivity to the EU's Eastern Partnership, deemed as an encroachment on Moscow's sphere of influence with important security implications (Gretskiy et al 2014). Ukraine, in particular, was at the forefront of Russia's efforts to protect its region through securing its membership in the EAEU.

\footnotetext{
${ }^{19}$ Joint Press Conference, St. Petersburg, 4 June 2012. http://kremlin.ru/transcripts/15541 (accessed 28 November 2018).

${ }^{20}$ Press remarks by Herman Van Rompuy, President of the European Council, following the EU-Russia Summit, St. Petersburg, 4 June 2012.

https://www.consilium.europa.eu/uedocs/cms_data/docs/pressdata/en/ec/130608.pdf (accessed 28 November 2018).

21 Joint Press Conference, St. Petersburg, 4 June 2012. http://kremlin.ru/transcripts/15541 (accessed 28 November 2018).

${ }^{22}$ E.g. European Parliament, Resolution of 26 October 2012 on EU-Russia trade relations following Russia's accession to the WTO (2012/2695(RSP). https://eur-lex.europa.eu/legalcontent/EN/TXT/PDF/?uri=CELEX:52012IP0409\&from=EN (accessed 26 November 2018).

23 Speech by President Barroso at the Russia-European Union summit - Potential for Partnership conference, 21 March 2013. http://europa.eu/rapid/press-release_SPEECH-13-249_en.htm (accessed 29 August 2018).
} 
In early 2011 Moscow engaged in a comprehensive campaign to divert Ukraine from its course towards concluding an Association Agreement with the EU in favour of joining the Customs Union and its planned successor, the EAEU (Dragneva, Wolczuk 2015). At the time, Kyiv rejected unequivocally this path. Yet, as in the summer of 2013 the prospect for concluding the AA became realistic, Russia's campaign intensified adopting an array of costly trade and customs restrictions. The offensive peaked with the approach of the Eastern Partnership summit in Vilnius in November 2013, ultimately securing President Yanukovych's U-turn and the temporary abandonment of the AA. This scenario was also deployed in Armenia in early September 2013, where the combination between carrots and sticks succeeded in persuading Yerevan to accede to the EAEU (Ter-Matevosyan et al 2017). Trade and energy penalties were also applied to Moldova and Georgia, yet failed to prevent them from signing the AAs with the EU (Cenusa et al 2014). Notably, while the integration campaign was waged with a view of securing membership in the Eurasian bloc, it was explicitly led by Russia rather than by the Customs Union as a whole. Similarly, the range of promises and threats were made and acted upon by Russia with no other CU member joining in.

While the EU was aware of Russia's position, it was taken aback by the intensity of pressure applied by the Kremlin in the summer and autumn of 2013. ${ }^{24}$ All this set the view that the CU was Russia's geopolitical project as opposed to a voluntary regional economic arrangement. This coercive dimension of Eurasian integration became an added factor in resisting engagement with the EAEU. When President Putin renewed calls for a free-trade zone with the EU at the January 2014 Russia-EU summit, ${ }^{25}$ EU's official position was that 'EU trade agreements can interact constructively with the CU as long as WTO rules are applied and free decision-making guaranteed'. ${ }^{26}$

\section{The EAEU and the aftermath of the Ukraine crisis}

Following Russia's annexation of Crimea and the start of the hybrid war in Eastern Ukraine, the EU found itself in uncharted territory on multiple levels. Condemning the Kremlin's actions, the EU suspended the bilateral talks on the NBA in March $2014 .{ }^{27}$ In the following months, the EU introduced a set of individual restrictive measures and economic sanctions, to which Russia retaliated. As the political crisis deepened, the profundity of its consequences for the established European order was in plain view. Against this background, and contrary to the previous misgivings, EU-EAEU cooperation was promoted as 'not the answer to everything' but at least 'a start towards negotiating a new European institutional order to fill

\footnotetext{
${ }^{24}$ E.g. European Parliament Resolution of 12 September 2013 on the pressure exerted by Russia on Eastern Partnership countries (in the context of the upcoming Eastern Partnership Summit in Vilnius. http://www.europarl.europa.eu/sides/getDoc.do?pubRef=-//EP//NONSGML+TA+P7-TA-20130383+0+DOC+PDF+V0//EN (accessed 20 October 2018).

${ }^{25}$ Press Statement. http://en.kremlin.ru/events/president/news/20113.pdf (accessed 27 August 2018).

${ }^{26}$ Remarks by President of the European council Herman Van Rompuy following the $32^{\text {nd }}$ EU-Russia Summit, Brussels, 28 January 2014, http://www.consilium.europa.eu/media/23838/140834.pdf (accessed 27 August 2018).

27 Statement of the Heads of State or Government on Ukraine, Brussels, 6 March 2014. https://www.consilium.europea.eu/media/29285/14/1372.pdf (accessed 27 August 2018).
} 
the vacuum left by broken institutions that have been rejected by Moscow' (Krastev, Leonard 2014).

To start with, a mega-deal was seen as means of restoring peace. As France and Germany became involved in the Minsk process, the idea of engaging with the EAEU found traction: recognising the bloc and hence the Kremlin's regional leadership, it was suggested, might induce it to meet its part of the bargain on Eastern Ukraine. ${ }^{28}$ The European Parliament also recommended that the 'Commission should explore the modalities of EU cooperation with the Eurasian Economic Union'. ${ }^{29}$ Such a study was undertaken by the EEAS, ${ }^{30}$ with the process culminating in a letter from Commission President Junker to President Putin in November 2015 (Gotev 2015). While the EU identified some areas of potential cooperation, ultimately progress remained conditional on the implementation of the Minsk agreements, something confirmed in the spring of 2016 by EU's High Representative Mogherini as the basis for improving relations with Russia more generally. ${ }^{31}$

Similarly, a mega-deal was promoted as the response to the crisis of EU's European Neighbourhood Policy. By ignoring regional interdependencies and integration developments in Eurasia, it was argued, the EU steamrolled its Association Agreements forcing a choice between the EAEU and integration with the EU on the countries caught in-between (Sakwa 2014). As the then German Foreign Minister Steinmeier put it, 'we should ask ourselves ... whether we have overlooked the fact that it is too much for a country to have to choose between Europe and Russia.' ${ }^{32}$ A mega-deal was seen as the chance to develop 'inclusive' rather than 'divisive' integration by setting up a framework within which the 'in-between' countries can benefit from cooperation with both blocs (Ademmer, Lissovolik 2018). Some Russian experts went further by insisting that without a deal those countries may not be able to embark on the path of sustainable growth at all (Vinokurov 2017a).

Responding to the critique, the EU launched a review of the ENP in November 2015 indicating, among others, 'a strong interest in developing new ways of working with the neighbours of the neighbours.' ${ }^{33}$ This proposition, however, was tested in the trilateral talks between EU,

\footnotetext{
${ }^{28}$ Statements reported in Wagstyl, Khalaf (2014).

${ }^{29}$ European Parliament Resolution of 18 September 2014 on the situation in Ukraine and the state of play of EU-Russia relations. http://www.europarl.europa.eu/sides/getDoc.do?type=TA\&reference=P8-TA-20140025\&language $=E N$ (accessed 28 August 2018).

30 This was an internal study; its key elements were reported by Reuters, EU foreign policy chief's paper on EURussia relations - text. 15 January 2015. https://www.reuters.com/article/ukraine-crisis-eu-russia/eu-foreignpolicy-chiefs-paper-on-eu-russia-relations-text-idUSL6NOUU2T820150115 (accessed 26 November 2018).

${ }^{31}$ Remarks by High Representative/Vice-President Federica Mogherini at the press conference following the Foreign Affairs Council, 14 March 2016. https://eeas.europa.eu/headquarters/headquartershomepage/5490/remarks-by-high-representativevice-president-federica-mogherini-at-the-press-conferencefollowing-the-foreign-affairs-council_en (accessed 26 November 2018).

32 Speech by Dr Frank-Walter Steinmeier, Federal minister for Foreign Affairs, at the handover ceremony on 17 December 2013. https://www.auswaertiges-amt.de/en/newsroom/news/131217-bm-antrittsrede/258766 (accessed 28 August 2018).

33 Joint Communication to the European Parliament, the Council, the European Economic and Social Committee and the Committee of Regions, Review of European Neighbourhood Policy, Brussels, 18 November
} 
Ukraine and Russia on the EU-Ukraine Deep and Comprehensive Free Trade Area (DCFTA), which took place in 2014-2015. In those talks Russia raised a range of concerns related to the launch of the DCFTA (Dragneva, Wolczuk 2015). While the key issues under consideration, namely market access, customs cooperation, technical standards and SPS measures, fall within the core competences of the EAEU, it was clear that it was Russia rather than the EAEU in forefront. Notably, as during the campaign of 2011-2013, Russia's partners neither shared those concerns, nor were willing to partake in the sanctions war with Ukraine and the West. At the same time, while the EU focused on pragmatic, technical solutions, Russia's sensitivities proved to be rooted in deeper geopolitical considerations (Dragneva et al 2017). As the talks collapsed in December 2015, Russia's interest in trade liberalisation and rule-based solutions was in question even more.

Thus, it can be seen that all these proposals ran aground. Nonetheless, despite the experience accumulated in the process, the pressure for engagement with the EAEU has continued. Ironically, it has also remained blind to the developments within the EAEU itself since May 2014 when its founding treaty was signed, including the adverse effect of Russia's actions in Ukraine on the EAEU itself. The following sections will examine these developments, setting them against the context of EU's external policy fundamentals more generally.

\section{The EAEU as a unified regional actor}

A key argument for a region-to-region agreement with the EAEU is the need to reflect the legal reality: '[S]imilar to the EU, the EAEU concludes trade agreements with third countries and is represented by a Commission' (Felbermayr, Gröschl 2017). If the EAEU is a unified, institutionalised region, then maintaining relations with the EAEU member states as opposed to with its common bodies, can be deemed misguided. Upon closer inspection, however, the EAEU's image as an independent actor is deeply problematic. Not only are member states of primary importance in the Union's decision-making, but Russia's dominance within the organisation - especially in its external relations - is pronounced. This is evident both at the level of the EAEU's institutions and practice.

The weakness of common institutions

According to the EAEU Treaty, the organisation is endowed with its own international legal personality. ${ }^{34}$ This personality is manifest in its right to engage in international cooperation with states, international organisations, and international integration associations, and independently or jointly with the member states conclude international treaties on any matters within its jurisdiction. ${ }^{35}$ However, in terms of jurisdiction as well as negotiating process, the EAEU's role is limited.

2015. http://eeas.europa.eu/archives/docs/enp/documents/2015/151118_joint-communication_review-ofthe-enp_en.pdf (accessed 28 august 2018).

${ }^{34}$ Article 1.2 of the EAEU Treaty.

${ }^{35}$ Article 7.1 of the EAEU Treaty. 
The EAEU has been endowed with a range of powers, which are exercised by its bodies. ${ }^{36}$ Yet, the level of delegation to the Eurasian Economic Commission is not as extensive as it may be expected given the declared objectives of the EAEU and the alleged similarity with the European Commission. Among the common powers of the Union, for example, are matters of tariff and customs regulation, technical regulation and the imposition of trade defence measures. Even in those areas, however, national competences abound: the Common Customs Code, for example, contains numerous references to national legislation and the powers of national customs authorities. Furthermore, any delegation is always reversible. Any decision taken by the EEC can be contested by a disagreeing member states and revoked by the higher bodies of the EAEU (the Supreme Eurasian Economic Council, consisting of Heads of State, and the Intergovernmental Council, consisting of Heads of Government), which decide by consensus. It is notable also that the supranational powers of the Commission were actually reduced with the EAEU Treaty: for example, the EEC is not able any more to bring a member state before the Court of the Eurasian Economic Union in cases of nonimplementation (Dragneva 2018a). Ultimately, the Commission's activities are embedded in a hierarchical structure which reproduces the chains of political power of its member states. Against this background, the Commission has been found to tread cautiously and conservatively. ${ }^{37}$

Furthermore, outside the current scope of delegated powers remain a large number of policy areas, such as services, transport and investment, which are subject to various degrees of coordination. This reflects the limited interest of member states in committing to far-reaching integration. While a range of general objectives were agreed, these depend on the future consent and action of member states. In those matters, the Commission's task is to facilitate cooperation, but direct dealing with the member states remains essential.

The prominence of member states is cemented by the institutional process put in place to negotiate with third parties. The EAEU uses a two-track approach. With regard to matters within the common competences of the EAEU, negotiating teams consist of Commission members as well as member state representatives. Thus, the Commission never appears on its own in dealing with third parties. With regard to matters within member states' competences, such as services and investment, the Commission is excluded altogether: negotiations in such areas have proceeded directly with the member states under the general coordination of Russia (Vinokurov 2017b). Thus, regardless of the formal division of powers, the Commission's role is one of a facilitator of member states' dialogue rather than an independent negotiator.

Russia's dominance

\footnotetext{
${ }^{36}$ Article 8.2 of the EAEU Treaty.

37 This has attracted domestic criticisms, e.g. by Sergei Glaz'ev, President Putin's advisor, 'Glaz'ev o proval'nykh perspektivakh EAES. Politicheskii Kaleidoskop, 24 January 2017. http://k-politika.ru/glazev-o-provalnyxperspektivax-eaes/ (accessed 20 October 2018).
} 
In this set-up, Russia's prominence is notable. This is not only a result of its massive structural preponderance within the economy of the EAEU, which translates into a high degree of identification of the EAEU interest with Russia's interest (Giucci, Mdinaradze 2017). It is a reflection of the insufficient technical expertise within other member states in dealing with complex trade issues. As noted, '[o]nly two employees from Belarus have been involved in FTA talks at the operational level' (Valdai Club 2017: 32). Ultimately, it also represents the political reality underpinning the EAEU, which is largely based on a bilateral, Russia-centred hub-and-spoke patterns of interactions, where the loyalty of members is procured by the provision of collateral benefits, such as political support, cheap energy or enhanced security (Dragneva, Wolczuk 2017).

Indeed, Russia's dominance of the external agenda of the EAEU has been in evidence not only relation to its dealing with the EU, discussed above. The EAEU has concluded a FTA with Vietnam in 2015, a partial agreement with Iran and a non-preferential agreement with China in 2018. Engaging with those partners, however, was the result of Moscow's initiative and geopolitical interest. Vietnam, for example, has been Russia's trusted political ally and strategic partner in the Asia Pacific. The main attraction of entering an FTA was not its trade importance - Vietnam accounts for less than $1 \%$ of the EAEU's total trade, but its significance as the economic dimension of an important geopolitical shift (Fedorov 2018). Moscow's leadership has been notable in relations with China too. The initiative of linking the EAEU with China's Belt and Road Initiative was a Russian move announced at a high-level bilateral meeting without prior consultation with its EAEU partners. While the project was endorsed at a subsequent EAEU summit, it has not removed the preference of those partners to deal with China on a bilateral basis. Similarly, the EAEU's current negotiating agenda, including Israel, Singapore, India and Egypt, is defined by their significance for Russia's global agenda (Dragneva 2018b).

Furthermore, many of the potential economic benefits of the prospective EAEU deals relate to the development of investments, infrastructure and logistics, areas which fall outside the common competences of the EAEU. Yet, Russia has been keen to bring its EAEU partner's external dealings within the common EAEU framework to boost the bloc's geopolitical credentials. At the same time, it has supplemented the EAEU framework with its own bilateral arrangements: the FTA with Vietnam, for example, contains a chapter on services and investment, which applies only to Russia. More importantly, Moscow has not hesitated to depart from the common framework, such as when applying sanctions to the West and Ukraine. Notably, it has done this regardless of the harm inflicted upon the economic cohesion of the Union or the resulting costs for individual member states (Knobel' 2014). ${ }^{38}$ Thus, the

\footnotetext{
38 For example, in January 2016 President Putin imposed restrictions on Ukrainian exports prohibiting the transit from Ukraine to Kazakhstan via Russia (later extended to Kyrgyzstan). The alternative longer route via Belarus resulted in higher transaction costs, leading to a $45.5 \%$ decrease of Ukrainian imports into Kazakhstan in the first half of 2016, 'Putin extends ban on transit of goods from Ukraine to Kazakhstan and Kyrgyzstan', UAWire, 3 July 2018. https://uawire.org/putin-extends-ban-of-transit-of-goods-from-ukraine-to-kazakhstanand-kyrgyzstan (accessed 27 August 2018).
} 
expectation that the EAEU multilateral framework will constrain Russia, shifting its agenda from the military to the economic sphere (Krastev, Leonard 2014) has proved to be unfounded.

\section{Divergence of member states' interests}

It is notable that, unlike Russia, the primary interest of its partners has not been the EAEU's expansion but its consolidation and delivery of economic benefits. Similarly, there has been little commonality of approaches to the international agenda of the EAEU (Devyatkov 2017). EAEU members have acquiesced to Moscow's lead as part of a complex regional bargain. At the same time, they have been keen to retain a degree of flexibility within the organisation and autonomy in their external dealings. As already noted, Russia's partners have abstained from supporting its economic warfare with the West. Instead, Belarus and Kazakhstan have sought to profit by circumventing the sanctions regime.

Furthermore, given the continued sensitivity to Russia's regional dominance, they have sought to balance its power by maintaining and developing bilateral relations with key external partners, such as the China and the EU. Thus, while interest in developing EU-EAEU relations has been shown, the support for a mega-deal has increasingly become a matter of rhetoric. Instead, in December 2015 Kazakhstan completed a bilateral non-preferential agreement with the EU aiming to strengthen political dialogue and promote mutual trade and investments. In November 2017, Armenia signed a Comprehensive Partnership Agreement (CEPA) with the EU. Both agreements exclude matters falling within the core competences of the EAEU, such as tariff regulation. Nonetheless, CEPA contains extensive commitments related to services, investment, and sectoral regulatory approximation, and both frameworks chart an ambitious agenda, which can be developed by the bilateral bodies set up under the respective agreements.

\section{The EAEU and trade liberalisation}

As noted, for the EU entering into a trade agreement with a third party is premised on compliance with the WTO system, something found to be problematic in the case of Eurasian integration. Since the launch of the EAEU in 2015, Russia has been keen to argue that the bloc's set-up and functioning is consistent with the rules of the WTO. ${ }^{39}$ This claim, however, has been undermined by Russia's own WTO record.

Following Russia's first WTO trade policy review conducted in September 2016, for example, the EU commented on Russia's protectionist import substitution policy, the continued use of disproportionate SPS measures and unilateral, politically motivated imposition of trade and transit restrictions. ${ }^{40}$ As a result, the EU continues to be embroiled in a number of high profile

\footnotetext{
${ }^{39} \mathrm{See}$, for example, press release of the Ministry of Economic Development of the Russian Federation, following the meeting of the WTO Committee on Regional Trade Agreements, 19 November 2018, http://economy.gov.ru/minec/about/structure/deptorg/201819118 (accessed 28 November 2018). ${ }^{40}$ European External Action Service, WTO Review: EU calls on Russia to abandon import substitution measures. Press Release, 28 September 2016. https://eeas.europa.eu/headquarters/headquarters-
} 
trade dispute with Moscow, several of which have been brought before the WTO. While Moscow has participated in the WTO dispute resolution process, its compliance with rulings is problematic, such as in the case of live pigs and pork imports from the EU (TASS 2018). EU's negative assessment has also been shared by the US in a succession of reports by the US Trade Representative on Russia's WTO record. They culminate in a blunt and damning statement in the 2017 report: 'So far, Russia's actions strongly indicate that it has no intention of complying with many of the promises it made to the United States and other WTO Members. [...] It was a mistake to allow Russia to join the WTO if it is not fully prepared to live by WTO rules. ${ }^{41}$

Such assessments reflect on the EAEU system as a whole. This is most evident to the extent in which the EAEU is charged with implementing Russia's WTO commitments, e.g. in relation to tariffs or technical standards. Problems are exhibited, however, also in situations where Russia's measures represent unilateral departures from the EAEU framework. This only serves to expose the limited nature and weak rules-based constraints of the organisation.

Further doubt on the EAEU's commitment to trade liberalisation is provided by its own record of concluding agreements with third parties. While the free trade agreement with Vietnam covers $88 \%$ of trade in goods, it is explicitly protectionist. For example, it exempts key commodities, provides the EAEU with a trigger safeguard mechanism regarding some sensitive goods and fails to remove the possibility to apply quotas and trade protection measures (Dragneva 2018b). This is partly in line with pressures within Russia itself, but also a way to secure EAEU consensus by limiting the liberalisation effects on members, such as Belarus. The agreement with Iran is very limited in scope and nature of commitments. It covers about 500 commodities, applying primarily a tariff concessions formula to comply with domestic restrictions in Iran, a non-WTO member. The agreement is an interim one, valid for a period of three years, after which a move towards a full trade area will be considered. Nonetheless, its compatibility with the WTO requirements for preferential agreements to cover 'all or substantially all trade' in goods is fundamentally problematic. Finally, the EAEU concluded an agreement with China in May 2018, yet this is a non-preferential accord and there is little interest to reach an FTA in the future. Instead, the agreement aims at improving customs cooperation and facilitating dialogue on the basis of the WTO framework.

In a similar vein, there is little evidence that the interest in an EAEU-EU deal entails liberalisation. Experts point to the limited benefit from a free trade component for either Russia or Kazakhstan, which dominate the EAEU's economy and whose exports to the EU are dominated by energy and raw materials (IIASA 2016). As the EEC Minister Valovaya states, the bloc's interest is in 'a non-preferential trade and investment agreement with the EU, but with more in-depth regulation of non-tariff barriers, mutual recognition of technical barriers to trade and sanitary - phytosanitary measures, facilitation of the customs procedures,

homepage/10713/wto-review\%E2\%80\%93eu-calls-on-russia-to-abandon-import-substitution-measures_en (accessed 28 November 2018).

41 US Trade Representative, 2017 Report on the Implementation and Enforcement of Russia's WTO Commitments. https://ustr.gov/sites/default/files/files/Press/Reports/Russia\%202017\%20WTO\%20Report.pdf 
cooperation in science, research and the digital economy'. ${ }^{42}$ Therefore, what is on the table relates at best to regulatory or sectoral cooperation. In principle, these are areas which can benefit from some commonality of standards, given that the EAEU has adopted certain EU templates (Emerson 2018). These are the areas, however, where the limits of EAEU's common competences are exposed, as discussed further above. Furthermore, as EU's experience in the trilateral talks on Ukraine's DCFTA showed, Russia has demonstrated little interest in customs facilitation or regulatory cooperation outside the context of its geopolitical agenda.

\section{The EAEU and the question of values}

The need for respect for values, such as democracy and the rule of law, human rights and fundamental freedoms, and the observance of international law, has been a fundamental part of EU's bilateral relations with EAEU members to date. It has featured in the PCAs as well as in subsequent policy frameworks, albeit with questionable robustness. While EU's concerns about democracy and human rights in Belarus precluded the ratification of the PCA, this was not the case with regard to the Central Asian countries. Neither has the EU moved to activate the PCA 'essential elements' clause despite the presence of grounds for it in those countries (Berdiyev 2003).

Nonetheless, for Russia EU's values conditionality has represented an important dimension of the EU's normative expansion and has underpinned its insistence on an equal relationship with Brussels (Haukkala 2010). More recently, it challenged the extent to which Europe qualifies as a normative power at all as well as developed alternative interpretations of human rights (Romanova 2016). It also challenged Western conceptions of sovereignty and international law, culminating in the annexation of Crimea (Allison 2014, OSCE 2015). Thus, the crisis in EU-Russia relations has become a 'normative war', where '[W]e have completely different visions of what is legitimate, what is desirable, what drives and what should drive policies and politicians' (Liik 2018). While Western concerns about authoritarian practices and the state of human rights in Russia have risen, so has Moscow's backlash to the Western order.

All this makes it very unlikely that Russia will agree to any values conditionality being part of an EU-EAEU framework. It has to be noted that human rights clauses are absent from some EU's agreements with developed countries (Bartels 2005). Yet, adherence to shared values is invariable affirmed within the broad policy context, as in the recent Comprehensive Economic and Trade Agreement with Canada. Thus, there remains the question to what extent can the EU afford to exclude the explicit reference to values from a cooperation framework with the EAEU or abstain from seeking reassurance about the shared understanding and compliance with international norms and principles. This is also problematic given that the EU has continued to rely on 'essential element' clauses in its latest agreements with both Kazakhstan and Armenia. ${ }^{43}$

\footnotetext{
42 Reported by IIASA (2017: 12).

${ }^{43}$ Article 1 of the Enhanced Partnership and Cooperation Agreement with Kazakhstan and Article 2 of the Comprehensive Enhanced Partnership Agreement with Armenia.
} 
As mentioned, Russia has been keen to assert the purely economic nature of the EAEU. The founding treaty of the EAEU does not include references to any political norms or shared values. In fact, it explicitly provides that the integration process should not impinge on the specificity of domestic systems. ${ }^{44}$ It has no good governance dimension and does not seek to reform domestic institutions. Thus, the EAEU is clear in the extent to which it seeks to perpetuate the existing political order of its member states. The EAEU's formal set-up reproduces the domestic hierarchies of executive power, dominated by strong and omnipotent presidencies (with some exceptions in Armenia). Similarly, the glue of the EAEU is Kremlin's ability to cater to the preferences of fellow authoritarian rulers for consolidation of power reducing the need for disruptive reforms. In this sense, the EAEU insulates the EAEU region from external democratising influences.

\section{Conclusion}

In principle, engaging with Eurasian integration could offer important benefits for the EU. However, this remains a highly hypothetical proposition. As argued in this chapter, this is not just because of the political context of EU-Russia relations. In its current state, the EAEU exhibits a number of fundamental problems in relation to both institutions and practice. While in formal terms the EU is asked to deal with the EEC, dealing with member states remains essential. Critically, this masks Russia's prominence within the organisation as well as its geopolitical motivation. At the same time, despite toying with the idea of a free trade in the past, it is evident that trade liberalisation is not on the agenda for Russia or the EAEU. In these circumstances, for the EU there remains the question as to whether the sole contribution of a mega-deal will be to secure a political trophy for Moscow, while condoning a form of regionalism which applies a highly selective standard to compliance with the WTO rules. It will further need to consider the extent to which an engagement with the EAEU will amount to legitimising authoritarian integration on its doorstep. It is equally concerning whether, given Russia's primary motivation and the weak rules-based framework of the EAEU, the EU will have any guarantees that Russia will abide by the rules agreed in a mega-deal.

On balance, moving away from a bilateral engagement towards a regional mega deal will entail some important departures from EU's principles and approach to external trade relations more generally. It is essential for any policy debates on dealing with the EAEU to be cognisant of the depth of these challenges.

\section{References}

Ademmer E, Lissovolik (2018) Thoughts on Inclusive Economic Integration. In: Charap S, Demus A, Shapiro J (2018) Getting Out from 'In-Between' Perspectives on the Regional Order in Post-Soviet Europe and Eurasia. Rand: Washington DC

\footnotetext{
${ }^{44}$ Article 3 of the EAEU Treaty.
} 
Aggarwal V, Fogarty E (2004) EU Trade Strategies: Regionalism and Globalism. Palgrave Macmillan: London

Allison R (2014) Russian 'deniable' intervention in Ukraine: how and why Russia broke the rules. International Affairs 90:6, pp. 1255-1297

Bartels L (2005) Human Rights Conditionality in the EU's International Agreements. OUP: Oxford

Berdiyev B (2003) The EU and former Soviet Central Asia: An Analysis of the Partnership and Co-operation Agreements. Yearbook of European Law 22:1, pp 463-481

Bertelsmann Stiftung (2016) Free Trade from Lisbon to Vladivostok. Focus Paper. https://www.bertelsmannstiftung.de/fileadmin/files/BSt/Publikationen/GrauePublikationen/NW_Focus_Paper_EU_Eurasia. pdf (accessed 26 November 2018)

Bordachev T (2015) Russia and the Eurasian Economic Union: the View from Moscow. ECFR Commentary, 21 January 2015. https://www.ecfr.eu/article/commentary_russia_and_the_eurasian_economic_union_th e_view_from_moscow403 (accessed 26 November 2018)

Bosse G, Korosteleva E (2009) Changing Belarus? The Limits of EU Governance in Eastern Europe and the Promise of Partnership. Cooperation and Conflict 44:2, pp. 143-165

Casier T (2018) EU-Russia Relations in Crisis: The Dynamics of a Breakup. In: Casier T, DeBardeleben J (eds) (2018) EU-Russia Relations in Crisis: Understanding Diverging Perceptions. Routledge: London.

Cenusa D, Emerson M, Kovziridse T, Movchan V (2014) Russia's Punitive Trade Policy Measures towards Ukraine, Moldova and Georgia. CEPS Working Document No 400/September 2014. https://www.ceps.eu/system/files/WD\%20300\%20Punitive\%20Trade\%20Measures\%20by\%20Rus sia_0.pdf (accessed 26 November 2018)

Chizhov V (2017) Statement at the 10 ${ }^{\text {th }}$ Eurasian Economic Forum. 23 October 2017. https://russiaeu.ru/en/ambassador-vladimir-chizhov-s-statement-10th-eurasianeconomic-forum (accessed 26 November 2018)

Connolly R (2013) Russia, the Eurasian Customs Union and the WTO. In Dragneva R, Wolczuk K (eds) (2013) Eurasian Economic Integration: Law, Policy and Politics. Edward Elgar, Cheltenham, pp 61-80

Cooper J (2009) Russia's Trade Relations with the Commonwealth of Independent States. In: Rowe E W, Torjesen S (eds) The Multilateral Dimension in Russian Foreign Policy. Routledge: Abingdon

Cooper J (2013) The Development of Eurasian Economic Integration. In: Dragneva R, Wolczuk K (eds) (2013) Eurasian Economic Integration: Law, Policy and Politics. Edward Elgar: Cheltenham, pp 15-33 
Crouch D (2013) Foreign Trade: now Russia is in the WTO, will it obey the rules?. Financial Times, 17 June 2013. https://www.ft.com/content/1b2f0c2a-cf62-11e2-a05000144feab7de (accessed 26 November 2018)

Delcour L, Wolczuk K (2013) Eurasian Economic Integration: Implications for the EU Eastern Policy. In Dragneva R, Wolczuk K (eds) (2013) Eurasian Economic Integration: Law, Policy and Politics. Edward Elgar: Cheltenham, pp 179-203

Devyatkov A (2017) The EAEU's International Ties up to 2015. In RIAC (2017) EAEU Development Prospects up to 2025. Working paper. http://russiancouncil.ru/papers/EAEU2025-Paper-en.pdf (accessed 26 November 2018)

Dragneva R (2004) Is 'Soft' Beautiful?: Another View on Law, Institutions and Integration in the Commonwealth of Independent States. RCEEL 29:3, pp 279-324

Dragneva R (2013) The Legal and Institutional Dimensions of the Eurasian Customs Union. In Dragneva R, Wolczuk K (eds) (2013) Eurasian Economic Integration: Law, Policy and Politics. Edward Elgar: Cheltenham, pp 34-60

Dragneva R (2018a) The Eurasian Economic Union: balancing sovereignty and integration. In: Petrov R, Van Elsuwege P (eds) (2018) Post-Soviet Constitutions and Challenges of Regional Integration. Routledge: Abingdon/New York, pp 48-70

Dragneva R (2018b) The Eurasian Economic Union: Putin's Geopolitical Project. FPRI, October 2018. https://www.fpri.org/wp-content/uploads/2018/10/rpe-6-dragnevafinal2.pdf (accessed 26 November 2018)

Dragneva R, De Kort J (2007) The Legal Regime for Free Trade in the Commonwealth of Independent States. International and Comparative Law Quarterly 56, pp 233-266

Dragneva R, Wolczuk K (2012) Russia, the Eurasian Customs Union and the EU: Cooperation, Stagnation or Rivalry? Chatham House Briefing Paper REP BP 2012/01. https://www.chathamhouse.org/sites/default/files/public/Research/Russia\%20and\%20E urasia/0812bp_dragnevawolczuk.pdf (accessed 26 November 2018)

Dragneva R, Wolczuk K (2015) Ukraine between the EU and Russia. Palgrave Pivot: Basingstoke/New York

Dragneva R, Wolczuk K (2017) The Eurasian Economic Union: Deals, Rules and the Exercise of Power. Chatham house Research Paper, May 2017. https://www.chathamhouse.org/sites/default/files/publications/research/2017-05-02eurasian-economic-union-dragneva-wolczuk.pdf (accessed 26 November 2018)

Dreyer I (2016) EU-EEU ties a matter of when not if. BNE Intellinews, 1 February 2016. http://www.intellinews.com/eu-eeu-ties-a-matter-of-when-not-if-89728/ (accessed 25 October 2018) 
Emerson M (2018) Prospects for 'Lisbon to Vladivostok': Limited by a double asymmetry of interests, CEPS Commentary, 12 June 2018. https://www.ceps.eu/publications/prospectslisbon-vladivostok-limited-double-asymmetry-interests (accessed 26 November 2018)

Euractiv (2012) Putin to visit Brussels as 'Eurasian Union' leader. 4 December 2012. https://www.euractiv.com/section/economy-jobs/news/putin-to-visit-brussels-aseurasian-union-leader/ (accessed 25 October 2018)

European Parliamentary Research Service (EPRS) (2017) Eurasian Economic Union: The Rocky Road to Integration. Briefing, April 2017.

http://www.europarl.europa.eu/RegData/etudes/BRIE/2017/599432/EPRS_BRI(2017)599 432_EN.pdf / (accessed 25 October 2018)

Fedorov N (2018) Soglashenie o zone svobodnoi torgovli mezhdu EAES I Vietnamom kak factor Rossiisko-v'etnamskikh otnoshenii. Sravnitel'naia Politika i geopolitika 9:1, pp 7490

Felbermayr G, Gröschl J (2017) Free Trade from Lisbon to Vladivostok: Who Gains, Who Loses from a Eurasian Trade Agreement?. CESifo Forum 2/2017 June, Volume 18. https://www.cesifo-group.de/DocDL/CESifo-Forum-2017-2-felbermayr-groeschleurasian-free-trade-june.pdf (accessed 26 October 2018)

Giucci R, Mdinaradze A (2017) The Eurasian Economic Union - Analysis from a trade policy perspective. Berlin Economics, 11 April 2017. https://berlin-economics.com/wpcontent/uploads/EAEU-11-April-2017_en.pdf (accessed 26 November 2018)

Gotev G (2015) Junker Opens the Door to EU-Eurasian union rapprochement. Euractiv. 20 November 2015. https://www.euractiv.com/section/economy-jobs/news/juncker-opensthe-door-to-eu-eurasian-union-rapprochement/ (accessed 26 November 2018)

Gretskyi I, Treshchenko E, Golubev K (2014) Russia's Perceptions and misperceptions of the EU Eastern Partnership. Communist and Post-Communist Studies 47:3-4, pp 375-383

Gstohl S, Hanf D (2014) The EU's Post-Lisbon Free Trade Agreements: Commercial Interests in a Changing Constitutional Context. European Law Journal 20:6, pp 733-748

Haukkala H (2008) Russian Reactions to the European Neighborhood Policy. Problems of Post-Communism, 55:5, pp 40-48

Haukkala H (2010) The EU-Russia Strategic Partnership: The Limits of Post-Sovereignty in International Relations. London \& New York: Routledge.

Hillion C (1998) Partnership and Cooperation Agreements between the European Union and the New Independent States of the Ex-Soviet Union. European Foreign Affairs Review 3, pp 399-420.

International Institute for Applied Systems Analysis (IIASA) (2016) Challenges and Opportunities of Economic Integration within a Wider European and Eurasian Space. 
Synthesis Report. http://pure.iiasa.ac.at/id/eprint/13982/1/18-01-

17\%20Final\%20Eurasian\%20project\%20report.pdf (accessed 26 November 2018)

IIASA (2017) Challenges and Opportunities of Economic Integration within a Wider European and Eurasian Space. Workshop Report. August 2017.

http://pure.iiasa.ac.at/id/eprint/14899/1/High-

level\%20meeting\%20June_Workshop\%20report.pdf (accessed 26 October 2018)

International Peace Institute (IPI) (2016) Economic connectivity: A Basis for Rebuilding Stability and Confidence in Europe?. October 2016. https://www.ipinst.org/wpcontent/uploads/2016/10/1610_Economic-Connectivity.pdf (accessed 26 October 2018)

Knobel' A (2014) Nevozmozhnaia troitsa; kak rossiiskie sanktsii razrushaiut Tamozhennyi soiuz. Forbes.ru, 2 December 2014. http://www.forbes.ru/mneniyacolumn/gosplan/274627-nevozmozhnaya-troitsa-kak-rossiiskie-sanktsii-razrushayuttamozhennyi (accessed 26 October 2018)

Krastev I, Leonard M (2014) The New European Disorder. ECFR, 20 November 2014. https://www.ecfr.eu/page/-/ECFR117_TheNewEuropeanDisorder_ESSAY.pdf (accessed 26 November 2018)

Liik K (2018) Winning the Normative War with Russia: An EU-Russia Power Audit. ECFR, 21 May 2018. https://www.ecfr.eu/page/-/EU-RUSSIA_POWER_AUDIT_.pdf (accessed 26 November 2018)

Lynn J (2009) WTO in confusion after Russia customs union plan. Reuters, 18 June 2009. https://www.reuters.com/article/us-trade-wto-russia-analysis/wto-in-confusion-afterrussia-customs-union-plan-idUSTRE55H18920090618 (accessed 26 November 2018)

Meister S (2015) Pragmatism, not Politicization. GGAPstadpunkt, Nr.4/ 29 June 2015. https://dgap.org/en/think-tank/publications/dgapviewpoint/pragmatism-notpoliticization (accessed 25 November 2018)

OSCE (2015) Back to Diplomacy. Final Report and Recommendations of the Panel of Eminent Persons on European Security as a Common Project. November 2015. https://www.osce.org/networks/205846?download=true (accessed 26 November 2018)

Romanova T (2016) Russian Challenge to EU's Normative Power: Change and Continuity. Europe-Asia Studies 68:3, pp 371-390

Roth M (2009) Bilateral Disputes between EU Member States and Russia. CEPS Working Document No. 319/August 2009. http://citeseerx.ist.psu.edu/viewdoc/download?doi=10.1.1.523.3873\&rep=rep1\&type=p df (accessed 27 November 2018)

Sakwa R (2014) Frontline Ukraine: Crisis in the Borderlands. IB Taurus: London Shishkov I (2001) Integratsionnye protsessy na poroge XXI veka. Moscow 
TASS (2018) Russia blocks establishment of conciliation panel in pork dispute with EU. http://tass.com/economy/1028529DS475 (accessed 28 November 2018).

Ter-Matevosyan V, Drnoian A, Mkrtchyan N, Yepremyan T (2017) Armenia in the Eurasian Economic Union: Reasons for Joining and Its Consequences. Eurasian Geography and Economics 58:3, pp 340-360

Valdai club (2017) Towards the Great Ocean-5: From the Turn to the East to Greater Eurasia. Report, August 2017. http://valdaiclub.com/files/15300 (accessed 27 November 2018)

Van Der Loo G (2013) EU-Russia Trade Relations: It Takes WTO to Tango?'. Legal Issues of Economic Integration 40:1, pp 7-32

Van Elsuwege P (2012) Towards Modernisation of EU-Russia Legal Relations?. CEURUS EURussia paper, June 2012. http://ceurus.ut.ee/wp-content/uploads/2011/06/EU-RussiaPaper-51.pdf (accessed 27 November 2018)

Vinokurov E (2017a) EU-EAEU Mega Deal Amid a Relationship Crisis. Centre of Eurasian Studies. 14 August 2017. http://greater-europe.org/archives/3209 (accessed 26 October 2018)

Vinokurov E (2017b) The Eurasian Economic Union. Eurasian Development Bank, 17 October 2017. http://eabr.org/analytics/integration-research/cii-reports/evraziyskiyekonomicheskiy-soyuz (accessed 26 August 2018)

Wagstyl S, Khalaf R (2014) Merkel Offers Russia Trade talks Olive Branch. Financial Times, 26 November 2014. https://www.ft.com/content/93e5e066-757a-11e4-b1bf-00144feabdc0 (accessed 26 October 2018)

Woolcock S (2012) European Union economic diplomacy: the role of the EU in external economic relations. Ashgate: London

Woolcock S (2014) EU Policy on Preferential Trade Agreements in the 2000s: A Reorientation towards Commercial Aims. European Law Journal 20:6, pp 718-732 